\title{
ASSESSMENT OF THE WATER QUALITY OF LAKE PLASTIRA THROUGH MATHEMATICAL MODELLING FOR ALTERNATIVE MANAGEMENT SCENARIOS
}

\section{A. ANDREADAKIS* \\ C. NOUTSOPOULOS \\ E. GAVALAKI}

Selected from papers presented at the $8^{\text {th }}$ Conference on Environmental Science and Technology,

8 - 10 September 2003, Lemnos, Greece.

\author{
National Technical University of Athens, School of Civil Engineering, \\ Department of Water Resources Hydraulics and Maritime Works, \\ Sanitary Engineering Laboratory, \\ Iroon Polytechneiou 5, Zografou 15773, Athens, Greece
}

*to whom all correspondence should be addressed: fax: 2106528078,2107722899 e-mail: andre1@central.ntua.gr

\begin{abstract}
In the context of a research program regarding water quality management and protection plan for Lake Plastira, one of the main tasks was the establishment of a sound relationship between the minimum water level and the trophic state of the lake.

The study involves the application of a eutrophication-dissolved oxygen mathematical model (EUTRO-SEL) which describes various physical, chemical and biological processes taking place in a water body.

Three water management scenarios were examined in the context of the study, based on alternative minimal operating water levels $(782 \mathrm{~m}, 784 \mathrm{~m}$ and $786 \mathrm{~m})$.

According to the modelling results and the classification of the water bodies according to the recent standards and trends within the European Commission, the operation of Lake Plastira at a minimum water level of $786 \mathrm{~m}$ ensures very good water quality characteristics (Category I). The operation of the Lake Plastira at lower water levels between $782-784 \mathrm{~m}$, results in acceptable water quality that classify the lake into Category II.

Since in all three management scenarios the water quality is acceptable and describes a water body with at least good water quality, acceptable minimum operational water level, can be determined by other considerations (e.g. elasticity of demand, lanscape aesthetics, etc).
\end{abstract}

KEYWORDS: chlorophyll-a; eutrophication; lake Plastira; water management; water quality modelling

\section{INTRODUCTION}

Lake Plastira is an artificial water body located at the central and east side of Pindos mountains. The primary uses of the water of the lake include irrigation, energy production, recreational activi- ties and potable water supply for the city of Karditsa. The need for a rational management scheme aiming to satisfy the above mentioned demands without adverse environmental impacts has been recognised for some time and in this 
context a research team of the National Technical University if Athens has undertaken this task (NTUA, 2002).

One of the critical issues involving the establishment of a sound relationship between the minimum water level and the trophic state of the lake, is presented and discussed in this paper. The study involves the application of mathematical modelling. The mathematical model used is an eutrophication-dissolved oxygen model (EUTRO-SEL), developed in the Sanitary Engineering Laboratory of the National Technical University of Athens and applied to the particular case of Lake Plastira.

\section{GENERAL STRUCTURE OF THE MODEL}

The mathematical model used, describes various physical, chemical and biological processes taking place in a water body, through suitable terms in mass balance equations for each chemical biological and physical parameter examined. Direct solution of these equations is usually impossible for natural systems. Therefore, it was necessary to consider the continuous water body as a completely mixed cell, in order to transform the particularly complicated partial differential equations into more simplified ordinary differential equations. In finite difference form the continuity equation can be written as:

$V_{k} \frac{d C k}{d t}=\sum_{j}\left|-Q_{k j}\left(a_{k j} C_{k}+\beta_{k j} C_{j}\right)+E_{k j}^{\prime}\left(C_{j}-C_{k}\right)\right| \pm r_{k} V_{k}+w_{k}$

where: $C_{k}=$ concentration in cell k $\left(\mathrm{mg} \mathrm{l}^{-1}\right)$

$C_{j}=$ concentration in cell $\mathrm{j}$ contacted with cell k $\left(\mathrm{mg} \mathrm{l}^{-1}\right)$

$V_{k}=$ volume of cell $\mathrm{k}\left(\mathrm{m}^{3}\right)$

$Q_{k j}=$ net advective flow from cell $\mathrm{k}$ to cell $\mathrm{j}\left(\mathrm{m}^{3}\right.$ day $\left.^{-1}\right)$

$\alpha_{j k}, \beta_{k j}=$ finite difference weighting factors (dimensionless), $\beta_{k j}=1-\alpha_{j k}$

$E_{k j}=$ dispersion coefficient $\left(\mathrm{m}^{2}\right.$ day $\left.^{-1}\right)$

$A_{k j}=$ cross sectional area between cell k and j $\left(\mathrm{m}^{2}\right)$

$E_{k j}^{\prime}=\frac{E_{k k j}}{L_{k j}}=\left(\mathrm{m}^{3}\right.$ day $\left.^{-1}\right)$

$L_{k}=$ characteristic length of cell $\mathrm{k}(\mathrm{m}), L_{j}=$ characteristic length of cell $\mathrm{j}(\mathrm{m})$

$L_{k j}=\frac{L_{k}+L_{j}}{2}(\mathrm{~m})$

$r_{k}=$ reaction term for cell $\mathrm{k}\left(\mathrm{mg} \mathrm{l}^{-1} \mathrm{day}^{-1}\right)$

$w_{k}=$ external load into cell $\mathrm{k}\left(\mathrm{g} \mathrm{day}^{-1}\right)$
Using the above finite difference approach a set of mass balance equations was derived describing the transport and reaction phenomena regarding each specie (chlorophyll, phosphorus, nitrogen, dissolved oxygen, BOD and transparency).

\section{DESCRIPTION OF THE STUDY AREA}

Lake's Plastira trophic state assessment was achieved by assuming its total volume as a completely mixed cell. Thus by eliminating dispersion phenomena, a very important task was the estimation of its size, taking into account that the geometry of the lake is a function of the inflows and outflows. By analysing the results of the hydrological study (NTUA, 2002) the following equations correlating its volume, water level and area were produced:

$$
\begin{gathered}
W L(t)=770.572-0.0000593 V(t)^{2}+0.0791136 V(t)(2) \\
E(t)=0.843184 W L(t)-643.22
\end{gathered}
$$

where: $W L(t)$ : water level in the lake at time $\mathrm{t}(\mathrm{m})$ $V(t)$ : volume of the lake $\left(10^{6} \times \mathrm{m}^{3}\right)$,

$E(t)$ : area of the lake $\left(10^{6} \times \mathrm{m}^{2}\right)$.

The lake's Plastira volume at each time step $(\Delta \mathrm{t})$ was calculated by the following equations as a function of the net inflows-outflows $(\Delta \mathrm{Q})$ :

$$
V(t+\Delta t)=V(t)+\Delta Q \Delta t
$$

$$
\Delta Q=\sum Q_{\text {inflows }}-\sum Q_{\text {outflows }}
$$

\section{MODEL REACTION KINETICS}

Equation (1) was applied for chlorophyll-a (A), dissolved oxygen (DO), BOD (C), ammoniacal nitrogen $(\mathrm{NH})$, oxidized nitrogen $(\mathrm{NO})$, organic phosphorus (OP), inorganic phosphorus (IP) and transparency in terms of Secci Disks (SD), resulting in a set of nonlinear equations. The model reaction terms and the mechanisms described in the model through the kinetic expressions are briefly presented in the following paragraphs.

Phytoplankton: A multiple Monod expression was used to correlate the phytoplankton growth rate in terms of chlorophyll-a with the nitrogen and phosphorus concentrations. The effects of temperature and solar radiation intensity at different depths were taken into account through the use of appropriate corrective terms. The depletion of 
chlorophyll which is taking place due to death, endogenous respiration and settlement was described by first order kinetic expressions. The overall expression describing the rate of change of the concentration of chlorophyll-a is:

$$
\begin{gathered}
r_{A k}=\mu_{A^{-}}\left(K_{d A}+R_{A}+K_{S A}\right) A_{k}+w_{A k} \\
\mu=\mu_{\max } f(T) f^{\prime}(I) \frac{N}{K N+N} \frac{P}{K P+P} \\
f(T)=\mathrm{A}_{1}^{(\mathrm{T}-20)} \\
f^{\prime}(I)=\frac{F e}{K H_{k}}\left(e^{(-I o / I s) e\left(-K H_{k}\right)}-e^{(-I o / I s)}\right) \\
R_{A}=R_{A 0}+A_{2}^{T} \\
K_{d A}=K_{d A 20} A_{3}^{(T-20)} \\
K_{S A}=\frac{V_{A \max }}{H_{k}+B} \\
K_{N}=K_{N 0} A_{4}^{T}
\end{gathered}
$$

where: $\mu$ : phytoplangton growth rate $\left(\right.$ day $\left.^{-1}\right) ; \mu_{\max }$ : maximum phypoplangton growth rate $\left(\right.$ day $\left.^{-1}\right) ; I s$ : critical sunlight intensity (cal cm ${ }^{-2}$ day $\left.^{-1}\right) ; K_{N}$ : Monod kinetic constant for $\mathrm{N}\left(\mathrm{mg} \mathrm{l}^{-1}\right) ; K_{N 0}$ : Monod kinetic constant for $\mathrm{N}$ at $0^{\circ} \mathrm{C}\left(\mathrm{mg} \mathrm{l}^{-1}\right) ; A_{1}$, $A_{2}, A_{3}, A_{4}$ : temperature coefficients; $K_{d A}$ : phytoplangton death rate coeficient $\left(\right.$ day $\left.^{-1}\right) ; K_{d A 20}$ : phytoplangton decay rate coefficient at $20^{\circ} \mathrm{C}\left(\right.$ day $\left.^{-1}\right)$; $K_{S A}$ : sedimentation velocity coefficient $\left(\right.$ day $\left.^{-1}\right)$; $V_{A \text { max }}:$ maximum phytoplangton sedimentation velocity $\left(\mathrm{m} \mathrm{day}^{-1}\right) ; B$ : resuspension impact coefficient; $R_{A}$ : endogenous respiration coefficient $\left(\right.$ day $\left.^{-1}\right) ; R_{A 0}$ : endogenous respiration coefficient for $0^{\circ} \mathrm{C}\left(\right.$ day $\left.^{-1}\right)$; Io: surface light intensity $\left(\mathrm{cal} \mathrm{cm}^{-2}\right.$ day $\left.^{-1}\right) ; F$ : photoperiod.

Phosphorus: The two categories of phosphorus described in the model are the organic and the inorganic phosphorus. Since the hydrolysis rate of the particulate organic phosphorus to soluble organic phosphorus is rather rapid in comparison to the other processes taking place, it can be neglected from the model. Therefore the soluble organic (OP) and the soluble inorganic phospho- rus (IP) are the two parameters examined in this model. The organic phosphorus (OP) is produced due to the phytoplankton death and endogenous respiration. Decrease in the organic phosphorus concentration is associated with its conversion to inorganic form and sedimentation. The overall rate of change of organic phosphorus (OP), is:

$$
\begin{gathered}
r_{O P k}=\left(K_{d A}+R_{A}\right) A_{k} Y_{1}-\left(R_{P}+K_{S P}\right) O P_{k}+\mathrm{w}_{O P k} \\
R_{P}=R_{P 0}+A_{5} T \\
K_{S P}=\frac{V_{P \max }}{H_{k}+B}
\end{gathered}
$$

where: $Y_{1}$ : chlorophyll $\mathrm{P}$ content $\left(\mathrm{mgP}(\mathrm{mg} \mathrm{Chl})^{-1}\right)$; $R_{P}$ : OP conversion to IP coefficient $\left(\right.$ day $\left.^{-1}\right) ; R_{P 0}$ : OP conversion to IP coefficient at $0^{\circ} \mathrm{C}\left(\right.$ day $\left.^{-1}\right)$; $K_{S P}$ : P sedimentation velocity coefficient $\left(\right.$ day $\left.^{-1}\right)$; $V_{P \max }: \mathrm{P}$ maximum sedimentation velocity $\left(\mathrm{m} \mathrm{day}^{-1}\right)$; $A_{5}$ : temperature coefficient.

The concentration of inorganic phosphorus (IP) is increased due to the conversion of organic phosphorus to inorganic, while its decrease is related to the uptake of inorganic phosphorus for the phytoplankton growth. The overall expression for inorganic phosphorus (IP), is:

$$
r_{I P k}=R_{P} O P_{k}-\mu Y_{1} A_{k}+w_{I P k}
$$

Nitrogen: Since ammonification (i.e. conversion of organic nitrogen to ammoniacal nitrogen) is a rather rapid process only two forms of nitrogen were considered in the present model; ammoniacal $(\mathrm{NH})$ and oxidized nitrogen (NO). Internal source for ammoniacal nitrogen $(\mathrm{NH})$ is the phytoplankton death. Losses of $\mathrm{NH}$ occur as a result of phytoplankton uptake for its growth and the conversion to oxidized nitrogen (nitrification). The phytoplankton can utilize both $\mathrm{NH}$ and NO as nitrogen source, although it prefers ammoniacal nitrogen if they are equally available. The model describes the relative preference of the phytoplankton population towards $\mathrm{NH}$ instead of NO through an algal preference coefficient $\left(P_{N H}\right)$ :

$$
P_{N H}=\frac{0.96(N H)}{0.96(N H)+0.04(N O)}
$$

The overall rate of change for the ammoniacal nitrogen $(\mathrm{NH})$ can be written as: 


$$
\begin{gathered}
r_{N H k}=-\mu Y_{2} P_{N H} A k-R_{N} N H_{k}+Y_{2} K_{d A} A_{k}+w_{N H k} \\
R_{N}=R_{N 20} A_{6}^{(\mathrm{T}-20)}
\end{gathered}
$$

where : $Y_{2}$ : chlorophyll $\mathrm{N}$ content $\left(\mathrm{mgN}(\mathrm{mg} \mathrm{Chl})^{-1}\right)$; $R_{N}$ : nitrification rate coefficient $\left(\right.$ day $\left.^{-1}\right) ; R_{N 20}$ : nitrification rate coefficient for $20^{\circ} \mathrm{C}\left(\right.$ day $\left.^{-1}\right) ; A_{6}$ : temperature coefficient.

The oxidized form of nitrogen (NO) includes mainly nitrates, as the portion of nitrites for the $\mathrm{pH}$ values prevailing in such water bodies can be assumed negligible. Internal source of nitrates (NO) is nitrification whereas losses are related to the phytoplankton uptake and denitrification. The reaction term for $\mathrm{NO}$ is:

$$
r_{N O k}=-Y_{2} \mu\left(1-P_{N H}\right) A_{k}+R_{N} N H_{k}+w_{N O k}
$$

Organic Carbon: Organic carbon expressed in terms of $\mathrm{BOD}_{5}$, is produced internally due to phytoplankton death while losses include the mechanisms of oxidation of the organic matter and sedimentation. The overall rate of change of organic carbon $(\mathrm{C})$ can be written as:

$$
\begin{gathered}
r_{C k}=Y_{3} K_{d A} A_{k}-\left(R_{L}+K_{S A}\right) C_{k}+w_{C k} \\
R_{L}=R_{L 20} A_{7}^{(T-20)}
\end{gathered}
$$

where: $Y_{3}$ : BOD per chlorophyll; $R_{L}$ : BOD degradation coefficient (day $\left.{ }^{-1}\right) ; R_{L 20}$ : BOD degradation coefficient at $20^{\circ} \mathrm{C}\left(\right.$ day $\left.^{-1}\right) ; A_{7}$ : temperature coefficient.

Dissolved Oxygen: Dissolved oxygen production is taking place due to photosynthesis and reaeration, while losses are associated with the mechanisms of oxidation of the organic carbon, nitrification, endogenous respiration of the algae and benthic oxygen demand. The overall expression describing the rate of change of dissolved oxygen (DO), is:

$$
\begin{aligned}
& r_{D O k}=\frac{K a t}{H k}\left(D O S-D O_{k}\right)+Y_{4} A_{k} \mu_{\max } f^{\prime}(I)- \\
& \frac{S O D_{k}}{H k}-R_{L} C_{k}-4.5 R_{N} N H_{k}-Y_{3} R_{A} A_{k}+w_{D O k}
\end{aligned}
$$

where: $K_{\alpha t}$ : reaeration coefficient $\left(\right.$ day $\left.^{-1}\right) ; Y_{4}$ : Oxygen per chlorophyll $\left(\mathrm{mgO}_{2} \mathrm{mg}^{-1} \mathrm{Chl}\right.$.).
The values of the parameters employed in the model were taken from previous applications of the model (Andreadakis, 1992; Noutsopoulos et al., 1999).

\section{EXTERNAL VARIABLES}

In addition to the reaction kinetics a major task was the assessment of the seasonal variation of the external variables: a) temperature, b) solar intensity and photoperiod, c) inflows and outflows and d) external loads.

Temperature, Solar intensity and Photoperiod: The seasonal variation of temperature as well as the daily average intensity and photoperiod were determined from analysis of field measurements and expressed by the following equations:

$$
\begin{gathered}
T=3.8+10\left(1-\cos \frac{(t-76) 360}{365}\right) \\
I o=120+192\left(1-\cos \frac{(t-30) 360}{365}\right)
\end{gathered}
$$

$$
F=0.320+0.200\left(1-\cos \frac{(t-30) 360}{365}\right)
$$

Inflows and outflows: Three alternative water management scenarios have been examined in the context of the present study, based on the minimum operational water level. The three alternative scenarios are related with the operation of the lake Plastira at minimum water levels of : a) $782 \mathrm{~m}$, b) $784 \mathrm{~m}$ and c) $786 \mathrm{~m}$. According to the results of the hydrological study (NTUA, 2002) the most critical period in terms of minimum water level values is the 8 year period of January 1988-December 1995 (Figure 1). Thus the inflows and outflows of the lake Plastira have been calculated for this critical simulation period. External loads: The pollution loads entering lake Plastira are originated from surface runoffs (nonpoint sources) and point sources. Table 1 presents the pollutional loads of the non-point sources calculated according to the land use of the surrounding areas (NTUA, 2002).

Point source pollution is related to drainage effluents of the surrounding villages and the rivers and streams entering lake Plastira (Table 2) and is highly dependent on the season (NTUA, 2002). 


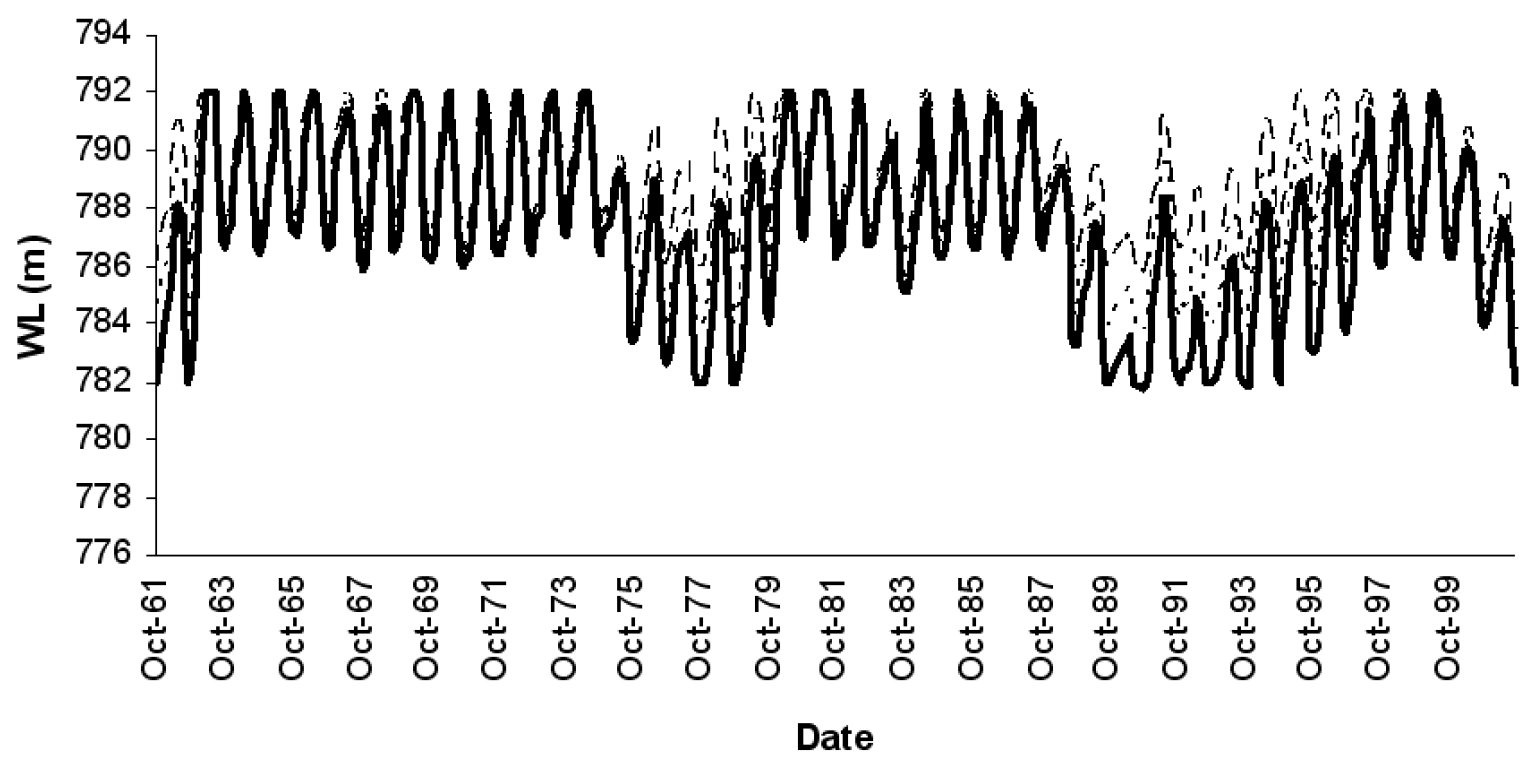

WL $782 \cdots \ldots$ WL $784----W L 786$

Figure 1. Time series of Lake's Plastira water level for three alternative management scenarios.

Table 1. Pollutional loads of non-point sources.

\begin{tabular}{ccc}
\hline Land use & Noads $(\mathbf{k g} / \mathbf{y e a r})$ & $\mathbf{P}$ \\
\hline Urban areas & 500 & 200 \\
Irrigation & 37500 & 1250 \\
Grassland & 20000 & 2000 \\
Forests & 25350 & 845 \\
Waters & 11200 & 560 \\
\hline Total & 91550 & 4855 \\
\hline
\end{tabular}

Table 2. Pollutional loads of point sources.

\begin{tabular}{cccc}
\hline Pollutional parameter & $\begin{array}{c}\text { Non-touristic period } \\
\text { Kg/year }\end{array}$ & Pollutionalparameter & $\begin{array}{c}\text { Touristic period } \\
\text { Kg/year }\end{array}$ \\
\hline BOD & 60827 & BOD & 92400 \\
SS & 27558 & SS & 41993 \\
N & 13907 & N & 21280 \\
P & 715 & P & 1129 \\
\hline
\end{tabular}

\section{MODEL APPLICATION AND RESULTS}

The simulation of the study area, as already mentioned, involved three alternative management schemes with respect to three alternative minimum operating water levels. The model simulation leads to the calculation of the daily depth average concentrations of the parameters examined, over the simulated 8-year period.
According to the results, for all the alternative management scenarios total nitrogen and phosphorus concentrations are low, whereas no significant differences regarding the dissolved oxygen concentrations were found, with dissolved oxygen concentrations always very high and close to the saturation values. Significant differences in the calculated organic carbon concentrations were realized, with 


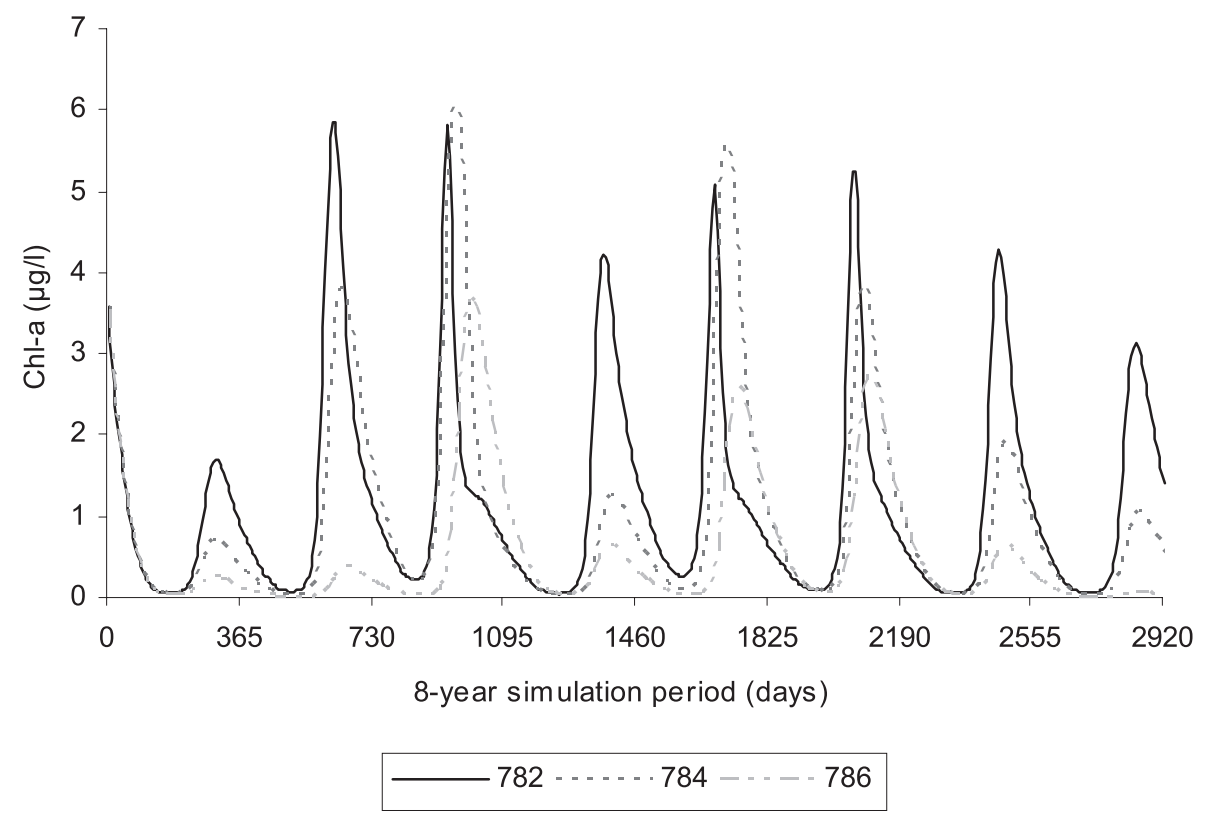

Figure 2. Variation of chlorophyll-a concentrations for three alternative management scenarios.

the maximum annual organic carbon concentrations for the scenario of minimum operating water level of $782 \mathrm{~m}$ being three to four times greater than those of the operating scenario of $786 \mathrm{~m}$.

With respect to chlorophyll-a concentrations, notable differences were found for the three examined alternative scenarios (Figure 2). In terms of maximum summer chlorophyll-a concentrations, the lower values $\left(0,3-3,6 \mu \mathrm{g} \mathrm{l}^{-1}\right)$ correspond to the minimum operating level of $786 \mathrm{~m}$. The differences with the other examined scenarios are significant, as the maximum summer chlorophyll-a concentration for the $784 \mathrm{~m}$ and 782 m scenarios ranged between 1-6,0 $\mu \mathrm{g}^{-1}$ and 3,2$6,0 \mu \mathrm{g} \mathrm{l}^{-1}$ respectively.

It must be noted that the chlorophyll-a concentrations predicted from the modelling application are very close to the range of monitoring data $(0,7-7,3$ $\mu \mathrm{g} \mathrm{l}^{-1}$ for minimum levels down to $782 \mathrm{~m}$ ), indicat- ing the reliability of the modelling approach.

As far as average chlorophyll-a concentrations are concerned, these reached 1,5-1,7 $\mu \mathrm{g} \mathrm{l}^{-1}$ for the $+782 \mathrm{~m}$ and $+784 \mathrm{~m}$ operating levels, with values lower than $1 \mu \mathrm{g} \mathrm{l}^{-1}$ for the $+786 \mathrm{~m}$ operating level scenario.

\section{CONCLUSIONS}

The qualitative assessment and trophic state classification on the basis of the results, presents difficulties due to the lack of a generally accepted classification system. Recent attempts towards a unified system of evaluation (EC, 2000; JRC, 2001) have been adopted in this study. According to these recent trends, a $10 \mu \mathrm{g} \mathrm{l}^{-1}$ average concentration and a $20 \mu \mathrm{g} \mathrm{l}^{-1}$ maximum concentration of chlorophyll-a can be considered as threshold values signifying eutrophication phenomena in lakes. On the basis of the results of this study it follows

Table 3. Water quality standards and classification of lakes according to maximum annual chlorophyll-a concentrations.

\begin{tabular}{cc}
\hline Maximum annual chlorophyll-a concentrations $\left(\boldsymbol{\mu \mathrm { g } \mathrm { I } ^ { - 1 }}\right)$ & Characterization/Classification \\
\hline$<5$ & Very Good Quality/ I \\
$5-10$ & Good Quality / II \\
$10-20$ & Fair Quality/ III \\
$20-50$ & Bad quality/ IV \\
$>50$ & Very bad quality/ V \\
\hline
\end{tabular}


that for all scenarios chlorophyll-a concentrations (both average and maximum) are significantly lower than these threshold values, therefore an acceptable trophic state is anticipated in all cases. However in the context of a more refined five grade water quality classification system, in accordance with the provisions of the Water Framework Directive 60/2000 (EC, 2000), a difference between the scenarios is observed (Table 3 ). According to the results of the mathematical modelling and the classification presented at Table 3, the operation of Lake Plastira at a minimum water level of $786 \mathrm{~m}$ ensures very good water quality characteristics, resulting in the classification of the lake to the Category I, while the operation at lower water levels between 782-784 $\mathrm{m}$, results in good water quality, that classify the lake into Category II.
Since in all three management scenarios the water quality is acceptable and describes a water body with at least good water quality, acceptable minimum operational water level, can be determined by other considerations (e.g. elasticity of demand, lanscape aesthetics, etc), which are outside the scope of this study and are discussed elsewhere (NTUA, 2002).

\section{ACKNOWLEDGEMENTS}

The authors wish to thank the Prefecture and Municipality of Karditsa for sponsoring the project and acknowledge the contribution of the other members of NTUA in the project, namely: K. Hatzimbiros, A. Katsiri, D. Koutsogiannis, A. Stamou, A. Balassopoulos, A. Efstratiadis, I. Katsiris, M. Kapetanaki, A. Koukouvinos, N. Mamasis, F. Sargentis and A. Christofidis.

\section{REFERENCES}

Andreadakis, A. (1992), The use of a water quality model for the evaluation of the impact of marine sewage disposal on the Evoikos Gulf, Water Science and Technology, 25, 165-172.

European Communities (2000), Directive 200/60 of the European Parliament and of the Council of 23 October 2000 establishing a framework for Community action in the field of water policy, O.J.L327, Vol. 43.

Joint Research Centre - European Commission (2001), Criteria for the identification of freshwater subjected to Eutrophication, Luxemburg, 2001.

NTUA, Department of Water Resources Hydraulics and Maritime Works (2002), Assessment of potential management and protection plans for Lake Plastira, Research program of NTUA, Final Scientific Report (in Greek).

Noutsopoulos C., Gavalaki E. and A. Andreadakis (1999), Evaluation of the impact from the discharge of treated sewage on the south-east Saronicos gulf through mathematical water quality modelling, Water Science and Technology, 39, 63-70. 